\title{
The settlement and the employee's material liability limits. Gloss to the Judgement of the Polish Supreme Court of 21 February 2018 (Ref.: III PK 14/17)
}

\section{Ugoda a granice odpowiedzialności materialnej pracownika. Glosa do wyroku Sądu Najwyższego} z 21 lutego 2018 r., III PK 14/17

dr hab. Grzegorz Wolak Assistant Professor at the Department of Private Law, Off-Campus Faculty of Law and Social Sciences of the Catholic University of Lublin in Stalowa Wola wolaczek@kul.pl

ORCID: 0000-0003-3636-8440

Summary In the gloss to the decision of the Polish Supreme Court of 21 February 2018, III PK 14/17, the author expresses his acceptance for the position that a non-judicial settlement obliging the employee who bears material liability under art. 114 of the Labour Code to pay compensation in excess of the limit under art.119 of the Labour Code is invalid (art. $58 \S 1$ of the Civil Code in connection with art. 300 of the Labour Code). Such a position of The Supreme Court is in line with the protective function of the labour law and the principle of the privilege to the employee and the principle of the limited material liability of the employee. In the same way, the author considered the issuance of the cassation ruling by the Supreme Court to be correct.

Keywords: employer, employee, damage, material liability, settlement.

Streszczenie W glosie do wyroku z 21 lutego 2018 r., III PK 14/17, autor wyraża aprobatę dla stanowiska Sądu Najwyższego, że ugoda pozasądowa zobowiązująca pracownika ponoszącego odpowiedzialność materialną na podstawie art. 114 k.p. do zapłaty odszkodowania w wysokości przewyższającej limit wynikający z art. 119 k.p. jest nieważna (art. 58 § 1 k.c. w związku z art. 300 k.p.). Pozostaje ono bowiem w zgodzie z funkcją ochronną prawa pracy, zasadami uprzywilejowania pracownika oraz ograniczonej odpowiedzialności materialnej pracownika. Tak samo za trafne autor uznaje wydanie w sprawie przez Sąd Najwyższy orzeczenia kasatoryjnego.

Słowa kluczowe: pracodawca, pracownik, szkoda, odpowiedzialność materialna, ugoda.

JEL: K31

Str. $44-50$

\section{Bibliography}

Bessaraba R. (1999). Odpowiedzialność materialna pracowników w orzecznictwie Sąu Najwyżzzego. Warszawa. Ćwiertniak, B. (2017). In: K. W. Baran (ed.). System prawa pracy. Tom I. Część ogólna. Warszawa.

Florek, L. (2016). Prawo pracy. Warszawa.

Góral, Z. (2017). In: K. W. Baran (ed.). System prawa pracy. Tom I. Część ogólna. Warszawa.

Jaskulska, M. (2018). Odpowiedzialność materialna pracownika za szkodę wyrządzoną pracodawcy., Przegląd Prawno-Ekonomiczny, (3).

Korus, P. (2018). W: A. Sobczyk (ed.). Kodeks pracy. Komentarz. Warszawa.

Lapierre, J. (1996). Ugoda sądowa w polskim procesie cywilnym. Przegląd Sądowy, (2).

Liszcz, T. (2016). Prawo pracy. Warszawa.

Muszalski, W. (2017). W. Muszalski (ed.). Kodeks pracy. Komentarz. Warszawa.

Radwański, Z. (1981). In: Z. Radwański (ed.). System prawa cywilnego, t. III, cz. 1. Prawo zobowiązań — część ogólna. Ossolineum. Radwański, Z. (1976). In: S. Grzybowski (ed.). System prawa cywilnego, t. III, cz. 2. Prawo zobowiązań — część szczegótowa. Ossolineum. Staszewska, E. (2013). Odpowiedzialność pracownicza. Warszawa.

Zieliński, T. (1986). Prawo pracy. Zarys systemu. Część I. Ogólna. Warszawa-Kraków. 